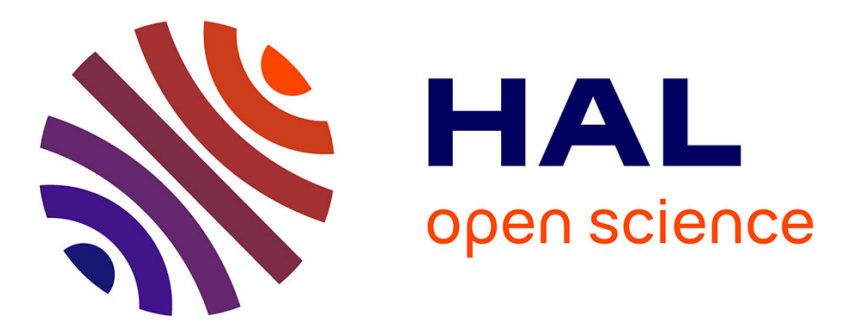

\title{
OXYGEN EFFECTS ON INTERNAL FRICTION AND MODULUS OF A TITANIUM ALLOY
}

\author{
B. Tittmann, L. Ahlberg, P. Beckham
}

\section{To cite this version:}

B. Tittmann, L. Ahlberg, P. Beckham. OXYGEN EFFECTS ON INTERNAL FRICTION AND MODULUS OF A TITANIUM ALLOY. Journal de Physique Colloques, 1985, 46 (C10), pp.C10-605C10-608. 10.1051/jphyscol:198510132 . jpa-00225336

\section{HAL Id: jpa-00225336 https://hal.science/jpa-00225336}

Submitted on 1 Jan 1985

HAL is a multi-disciplinary open access archive for the deposit and dissemination of scientific research documents, whether they are published or not. The documents may come from teaching and research institutions in France or abroad, or from public or private research centers.
L'archive ouverte pluridisciplinaire HAL, est destinée au dépôt et à la diffusion de documents scientifiques de niveau recherche, publiés ou non, émanant des établissements d'enseignement et de recherche français ou étrangers, des laboratoires publics ou privés. 
JOURNAL DE PHYSIQUE

Colloque $\mathrm{C} 10$, supplément au $\mathrm{n}^{\circ} 12$, Tome 46 , décembre 1985 page Cl0-605

\title{
OXYGEN EFFECTS ON INTERNAL FRICTION AND MODULUS OF A TITANIUM ALLOY
}

\author{
B.R. TITTMANN, L.A. AHLBERG AND P.M. BECKHAM \\ Rockwell International Science Center, 1049 Camino Dos Rios, \\ Thousand Oaks, CA 91360, U.S.A.
}

\begin{abstract}
Resume - Les effets de l'oxygene sur la friction interne, le module et la vitesse du son d' un alliage alpha/beta de titane diponible commercialement ont ete etudies dans un intervalle de temperature de 80 a $290 \mathrm{Kel} v i n$. L'attenuation generale decroit avec la concentration d'oxygene et un pic de friction interne observe entre 110 et 130 degres $K$ a presente un accroissement lorque la concentration d'oxygene augmentait. A temperature ambiante, les vitesses du son et par consequent les modules dependent du montant $d^{\prime}$ oxygene et peuvent croitre ou decroitre, suivant la direction de propagation, indiquant que la texture peut avoir un effet important. Les indications sont que le pic de friction interne est du a une transformation beta $\rightarrow$ omega dans la phase beta de l'alliage et que l'attenuation generale est causee par la solution solide d'oxygene dans la phase alpha. Ces resultats sont consistants avec les resultats de la litterature rapportes pour les phases individuelles.
\end{abstract}

Abstract - The effects of oxygen on the internal friction, modulus and sound velocity of a commercially available alpha/beta titanium alloy were investigated over a temperature range of 80 to $290^{\circ} \mathrm{K}$. The overall background damping decreases with oxygen concentration and an internal friction peak observed between 110 and $130^{\circ} \mathrm{K}$ was found to increase with increasing oxygen concentration. At room temperature, the sound velocities and therefore the moduli depend on the amount of oxygen and can either increase or decrease, depending upon the propagation direction, indicating that texture can have a strong effect. Indications are that the internal friction peak is due to a beta $\rightleftarrows$ omega transformation in the beta phase of the alloy and that the background damping is caused by the solid solution oxygen in the alpha phase. These data are consistent with literature data reported for the individual phases.

\section{I - INTRODUCTION}

The effects of the presence of interstitial oxygen on the mechanical properties of $\mathrm{Ti}$ and $\mathrm{Ti}$ alloys have been a subject of interest for some time. Most of the previous work has been done on pure beta phase alloys of Ti. Lately, there has been considerable interest in Ti-6211 because of its toughness and weldability $/ 1 \%$ Ti-6211 is primarily an $\alpha$-phase material with the $\beta$-phase embedded in the matrix. The purpose of these experiments is to determine the effects of interstitial oxygen on alpha/beta phase Ti alloys.

\section{II - EXPERIMENTAL PROCEDURES}

Internal friction and modulus measurements were performed on five Ti-6211 samples having from $0.075 \%$ to $0.29 \%$ oxygen. The $0.075 \%$ sample is typical of commercially available material. The temperature for the internal friction and corresponding Young's modulus measurements ranged from 80 to $290 \mathrm{~K}$. Further modulus results were obtained at room temperature using ultrasonic velocity measurements. 
The samples were cut from pieces that were rolled, annealed for $1 \mathrm{~h}$ at $925^{\circ} \mathrm{C}$, then air-cooled. Reference 1 gives a detailed description of the material. The internal friction samples were rectangular pieces $4.6 \mathrm{~cm}$ long, $0.5 \mathrm{~cm}$ wide and $0.2 \mathrm{~cm}$ thick, which resonated in a free-free flexural. mode with a frequency of about $5 \mathrm{KHz} / 2 \%$. The sample was placed in the inner chamber of a double Dewar system, evacuated, then $2 \mathrm{~mm} \mathrm{Hg}$ of He added as a thermal exchange gas. The sample was cooled at a rate of $0.5 \mathrm{k} / \mathrm{min}$, with data taken at 10 min intervals. The room temperature moduli were obtained from ultrasonic velocity measurements on cubes, $1.5 \mathrm{~cm}$ on a side, oriented with the three principal directions in the rolled plate material $(L, T, S)$.

\section{III - EXPERIMENTAL RESULTS}

The internal friction in $T i-6211$ as a function of temperature and oxygen content is shown in Fig. 1. The data exhibit a substantial peak centered at about $120 \mathrm{~K}$ with a half-width of about 40K. A similar peak has been seen and studied in other Ti alloys by Sommer et al $/ 3 /$ and Buck et al /4/. The peak is thought to arise as a result of a thermally activated relaxation process involving $\beta \overrightarrow{\neq} \omega$ phase transformation having an activation energy of $0.22 \mathrm{eV}$ and a relaxation time of $\tau_{0}=$ $2 \times 10^{-14} \mathrm{~s}$.

Fig. 1 Internal friction in $\mathrm{Ti}-6211$ as a function of temperature and oxygen content.

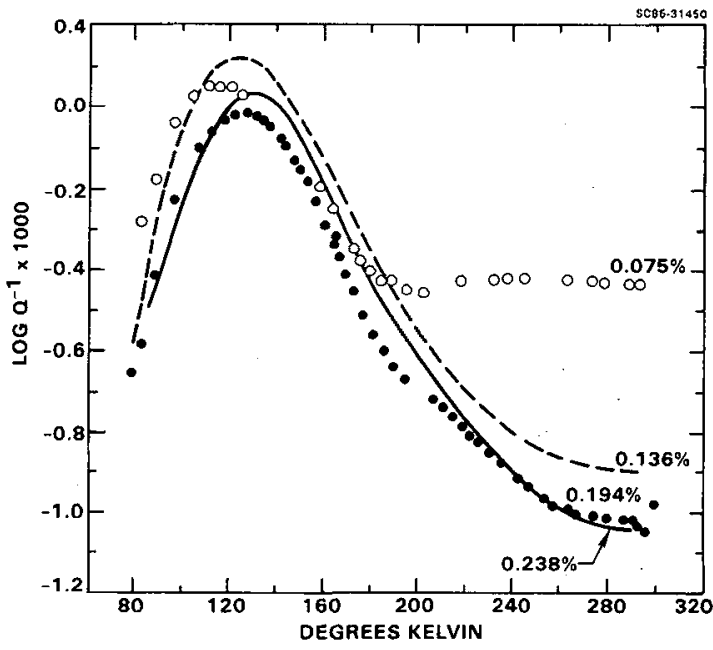

The width of the peak is about a factor of two, too broad for a single relaxation process. This is probably due to the presence of nuclei metastable w-phase in the $\beta$-phase. Reference 3 shows that the height of the internal friction peak is a function of alloy content and first increases with alloy addition, goes through a maximum, and then decreases with further additions. The data of fig. 1 show that the addition of oxygen increases the peak height. "This is consistent with the effect of alloy composition on peak height, i.e., when oxygen is added, the $\beta-$ phase material reacts as if the alloying is increased $/ 4 \%$. Thus, it appears that the $\beta$-phase is a low concentration alloy. Verification of this using STEM microanalysis of the $\beta$-phase has been started.

The high temperature background in the $0.075 \%$ oxygen data (180 to 290K portion) was found to strongly decrease with increasing oxygen. This effect has been observed by earlier investigators $/ 1 \%$, and was shown to be due to pinning of the $\alpha$-phase by oxygen $/ 1 /$. The $\beta$-phase does not show this effect $/ 3 /$. 
Fig. 2 Young's modulus in Ti -6211 as a function of temperature and oxygen content.

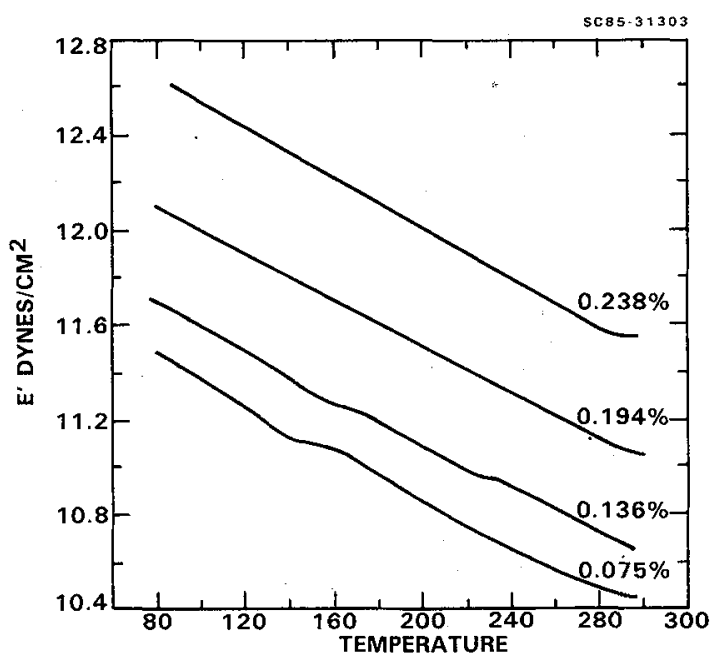

The results of the corresponding Young's modulus data from the internal friction measurements are shown in Fig. 2. The data show little small or no modulus defect, which is consistent with previous observations /4/ in other Ti alloys. The modulus is seen to increase with oxygen content, as expected, because the associated increase of the volume fraction of $\alpha$-phase material which has a higher modulus than the $\beta$-phase $/ 1 \%$.

To determine the directional dependence of the effects of oxygen on the modulus, shear and longitudinal measurements were made at ultrasonic frequencies in the principal propagation and polarization directions on a cube from each sample. The results of the shear data are shown in Fig. 3, and demonstrate that texture is playing an important role and may overshadow the effect of oxygen on the modulus.

SC85-31451
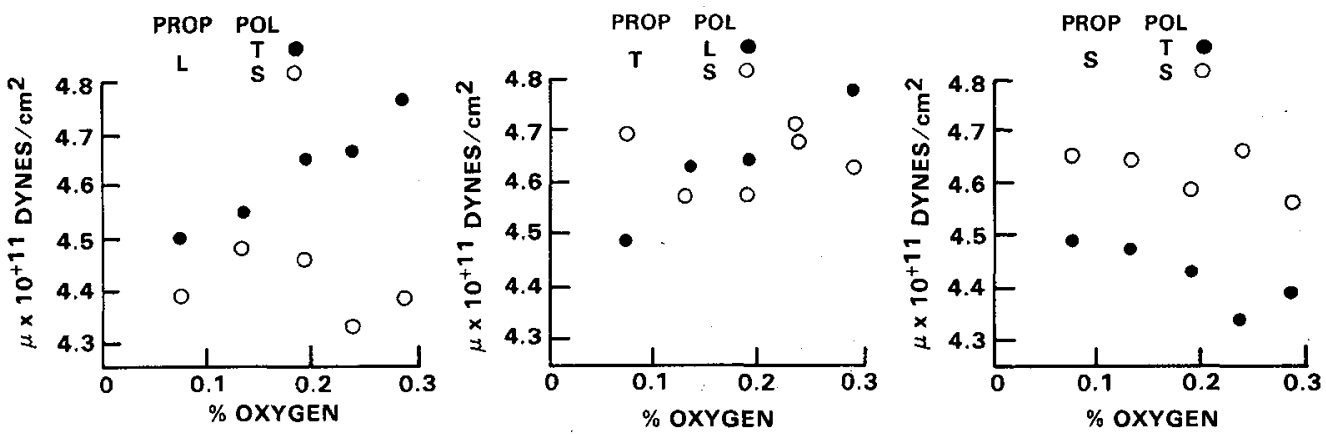

Fig. 3 Shear modulus in Ti-6211 as a function of oxygen content.

IV - CONCLUSION

Internal friction peaks have been found in an $\alpha / \beta$ Ti alloy. The results are consistent with the behavior expected for a $\beta$-phase of the material with low alloy concentration. Furthermore, the addition of oxygen acts as if there is a composition change to the alloy. The overall background damping decreases with increasing oxygen content. 
The ultrasonic velocity measurements reveal that both texture and oxygen affect the modulus.

\section{$V$ - ACKNOWLEDGEMENTS}

The authors are deeply indebted to Prof. Otto Buck, Iowa State University for his help in the interpretation of these data. We also thank Bob Housley for the use of his internal friction apparatus, and $H$. Chaskelis, NRL, who provided the samples.

\section{REFERENCES}

/1/ Buxbaum, S. R. and Green, R.E. Jr. , Non Destructive Methods for Material Property Determination. Plenum Press, (1984), Eds. Rudd and Green 271.

12/ Nowick, A. S. and Berry, B. S., Anelastic Relaxation in Crystalline Solids, Academic Press, New York, (1972) 627

13/ Sommer, A. W., Motokura, S., Ono, K., and Buck, 0., Acta Met. 21 (1973) 489.

14/ Buck, 0. Thompson, D. 0., Paton, N. E., and Williams, J. C. , Proc. V Int. Conf. on Internal Friction and Ultrasonic Attenuation in Crystalline Solids, Vol. 1, (1973), Eds. Lenz and Lucke 451 